\title{
TWO NEW SPECIES OF DELLIA STÅL, 1878 GRASSHOPPERS (ORTHOPTERA: ACRIDIDAE) FROM SIERRA DE BAHORUCO, DOMINICAN REPUBLIC
}

\author{
Daniel E. Perez-Gelabert ${ }^{1}$ and Daniel Otte ${ }^{2}$ \\ ${ }^{1}$ Department of Entomology, United States National Museum of Natural History, Smithsonian \\ Institution. P.O. Box 37012, Washington, DC 20013-7012, USA. perezd@si.edu \\ ${ }^{2}$ Department of Entomology, Academy of Natural Sciences. 1900 Benjamin Franklin Pkwy., \\ Philadelphia, PA 19103, USA. otte@acnatsci.org
}

\begin{abstract}
The acridid grasshoppers Dellia viridissima sp. nov. and Dellia ciceroana sp. nov. are described and illustrated from Sierra de Bahoruco, Dominican Republic. These species inhabit transition and mountain forests between $450-1,300 \mathrm{~m}$ elevation. D. viridissima sp. nov. was found in close association with the vine Solandra longiflora Tuss. (Solanaceae) suggesting that it could be an oligophagous specialist. D. ciceroana sp. nov. was collected in a more xeric transition forest at the sides of the trail from Puerto Escondido to the heights of the Sierra de Bahoruco National Park. The number of Dellia species known from Hispaniola is increased to six, three of these being from Sierra de Bahoruco.
\end{abstract}

Key words: description, taxonomy, Hispaniola, Caribbean, Greater Antilles, Dellia, new species.

\section{RESUMEN}

Se describen e ilustran los saltamontes acrídidos Dellia viridissima sp. nov. y Dellia ciceroana sp. nov. de la Sierra de Bahoruco, República Dominicana. Estas especies habitan bosques de transición y de montaña entre $450-1,300 \mathrm{~m}$ de elevación. $D$. viridissima sp. nov. fue encontrada en cercana asociación con la planta trepadora Solandra longiflora (Tuss.) (Solanaceae) sugiriendo que este saltamontes podría ser un especialista oligófago. D. ciceroana sp. nov. fue colectada en un bosque de transición más seco a los lados del camino desde Puerto Escondido a las alturas del Parque Nacional Sierra de Bahoruco. El número de especies de Dellia conocidas de La Hispaniola se incrementa a seis, de las cuales tres son de la Sierra de Bahoruco.

Palabras clave: descripción, taxonomía, La Hispaniola, Caribe, Antillas Mayores, Dellia, especies nuevas.

\section{INTRODUCTION}

The West Indian grasshopper genus Dellia Stål, 1878 (Orthoptera: Acrididae: Copiocerinae) was originally established to accommodate the species Dellia insulana from Cuba. A second species, Dellia multicolor, was later described by Carl (1916) also from Cuba, but it was recently synonymized with $D$. insulana by Amédégnato et al. (1995). Dellia was subsequently discovered in the Blue Mountains of Jamaica by Rehn \& Hebard (1938), who described Dellia gemmicula. In Hispaniola Dellia was discovered much more recently in several coastal and montane areas of the Dominican Republic (Perez-Gelabert et al., 1995; Perez-Gelabert \& Otte, 1999; PerezGelabert, 2002) and until now four species have been described (Dellia dominicensis, Dellia monticola, Dellia roseomaculata and Dellia bayahibe). Two other species of Dellia were discovered in the Cockpit Country of Jamaica (Dellia karstica and Dellia maroona) by PerezGelabert (2001). The genus has also been found to be distributed (with at least one undescribed species) in the Bahamas (Perez-Gelabert, 2000). Specimens from Cuba already in collection, 
indicate that several undescribed species are found on that island and those will be the subject of a future paper. So far Dellia grasshoppers have not been found in Puerto Rico. The two species described here, even though both are from Sierra de Bahoruco in the Dominican Republic, are very different from each other in their coloration and are readily distinguished from all previously described species.

\section{OBJECTIVE}

- To describe two additional species of the grasshopper genus Dellia from two different areas of Sierra de Bahoruco, Dominican Republic, island of Hispaniola.

\section{MATERIAL AND METHODS}

Specimens of both new species were compared with representatives of all described Hispaniolan Dellia. The type specimens plus some paratypes are deposited in the collection of the Academy of Natural Sciences, Philadelphia (ANSP). Other paratypes are in the collection of the National Museum of Natural History, Washington, DC (NMNH) and the Museo Nacional de Historia Natural, Santo Domingo (MNHNSD). In all our Hispaniolan Orthopteroids Project labels, the RD-\#\# designations are the locality numbers assigned to them (i.e., REPUBLICA DOMINICANA-\#\#). Photographs of specimen morphology were taken with a Nikon CoolPix 995 camera mounted on a Nikon SMZ 800 stereoscope. Male genitalia were extracted and cleared according to standard procedures using 10\% sodium hydroxide, washed in water and preserved in $80 \%$ Ethanol. Measurements are in millimeters and were made using an ocular micrometer in an Olympus SZH stereoscope.

\section{RESULTS}

Dellia viridissima $\mathrm{sp}$. nov.

Figures 1A; 2, A-H; 5

Diagnosis. This species is distinctive among Hispaniolan Dellia by its generally dark green coloration combined with yellow or orange bands on head and pronotum.

Description.- Coloration: generally dark green with yellow to sometimes orange spots and bands on head and pronotum. Head: vertex dark green to black surrounded by finer yellow bands interspersed with dark green around internal margin of eyes and continued over to fastigium. Yellow bands wider around anterior perimeter of eyes, perimeter completed by postero-ocular black band. Edges of frontal ridge and clypeus delineated by bright yellow to orange lines on dark green face background. Antenna green, white-tipped. Palps lighter green than face. Thorax: pronotum dorsally dark green with one bright yellow band on each lateral margin, interrupted at first sulcus and less marked posteriorly. Pronotal side marked by a discontinuous and fainter yellow band. Each epimeron with one undefined yellow patch on its lower half. Vestigial tegminae: whitish to light brown tinged with green and yellow. Abdomen: generally dark green, dorsally with small, ill-defined yellow blotches on each tergite adjacent to a yellowish to light brown medial line. Tympanum whitish to very light brown. Legs: fore and middle femora olive green, tibiae darker green. Hind femora bright olive green, with wide orange to yellowish area immediately proximal to black knees. Hind tibiae bluish green. In all legs tarsi reddish, claws black. External genitalia: furculae, epiproct, and subgenital plate light greenish and brown, cerci light brown with darkened tips. 
Morphology: both sexes small $(15-20 \mathrm{~mm})$ and slender. Body integument shiny but somewhat rugose, dorsally with sparse and relatively long hairs that grow more profusely on its ventral surface. Head: small and slightly globose, with vertex depressed between eyes. Fastigium produced to a small blunt triangle continued below by frontal ridge with non-parallel carinae. Antennae filiform, with 18-20 antennomeres, most about $3 \mathrm{X}$ longer than wide. Thorax: pronotum slightly longer than head length, saddle shaped, cut by three well-marked sulci and lacking medial carina. Anterior pronotal margin slightly produced forward and with medial concavity. Posterior pronotal margin only barely notched, its lateral margin straight without definitive lobe. Prosternal spine not exceedingly large, sub-pyramidal. Vestigial tegminae: markedly reduced, narrow and spatulate, only slightly longer than half length of eyes, barely reaching third abdominal tergum. Abdomen: abdominal tergites with marked dorsal carina. Tympanum present. Legs: cylindrical, robust in relation to body size and not carinated on dorsal or ventral surface. Hind femora not markedly thickened, knees smooth, without genicular spines. Hind tibiae pilose, with 6 external and 8 internal spines, the internal ones being slightly longer. Mesotarsus slightly shorter than protarsus, metatarsus nearly $1.5 \mathrm{X}$ as long as protarsus. External genitalia: furculae present, triangular. Epiproct sub-quadrangular, with both sides depressed below the level of a medial broadly flattened ridge, posteriorly tapering to widely produced tip over one third of length of epiproct. Internal genitalia (Fig. 2, A-F): epiphallus bridge-like with ancorae small, bridge width about half thickness of lateral process and nearly as long. Lophi rounded and well developed. Lateral epiphallic sclerites present and somewhat rounded. Ventrolateral sclerites large, cingulum with broad lateral rami and short, small apodemes, zygoma without prominent median process. Aedeagus very short, dominated by huge arch, which almost hides dorsal and ventral valve. Endophallic plate large, with large gonopore process.

Female. Colored very much like male, body larger and more robust. Valves of ovipositor rather slender and elongated, bearing few small teeth on dorsal surface. Subgenital plate wide, nearly quadrangular, terminating in very small medially produced tip (Fig. 2, G-H).

Etymology. Viridissima is a Latin superlative adjective used in reference to the markedly dark green coloration of this species. In this sense, it is rather unique among Hispaniolan Dellia.

Type material. HOLOTYPE: Male, DOMINICAN REPUBLIC, RD-012 18.i.2002, forest near La Mina, Cortico, Monteada Nueva, Barahona Prov., 1,250 m, 264-773mE 2003-753mN, R. Bastardo, B. Hierro, S. Medrano, D. Otte, D. Perez (ANSP). Paratypes: Five males and 3 females same data as holotype (ANSP, NMNH, MNHNSD). One male, DOMINICAN REPUBLIC,

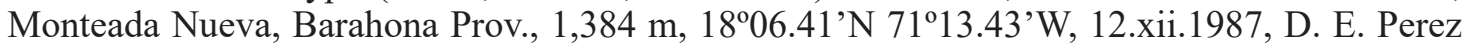
(NMNH).

Measurements (mm), 2 males, 2 females.- Paratype male 1: body length: 14.50; head length: 2.00; pronotum length: 2.75; interocular distance: 0.45 ; length of hind femur: 8.00. Paratype male 2: body length: 13.50; head length: 2.13; pronotum length: 2.50 ; interocular distance: 0.45 ; length of hind femur: 8.75. Paratype female 1: body length: 17.50; head length: 2.38; pronotum length: 3.16; interocular distance: 0.63 ; length of hind femur: 12.88 . Paratype female 2: body length: 17.50; head length: 2.38; pronotum length: 3.88; interocular distance: 0.63 ; length of hind femur: 12.25 .

\section{Dellia ciceroana sp. nov. \\ Figures 1B; 3, A-L; 5}

Diagnosis. This species can be diagnosed by the light brown coloration of the head and pronotum combined with the large whitish to yellowish blotches dorsally on the pronotum, while having the hind femora bright green. 

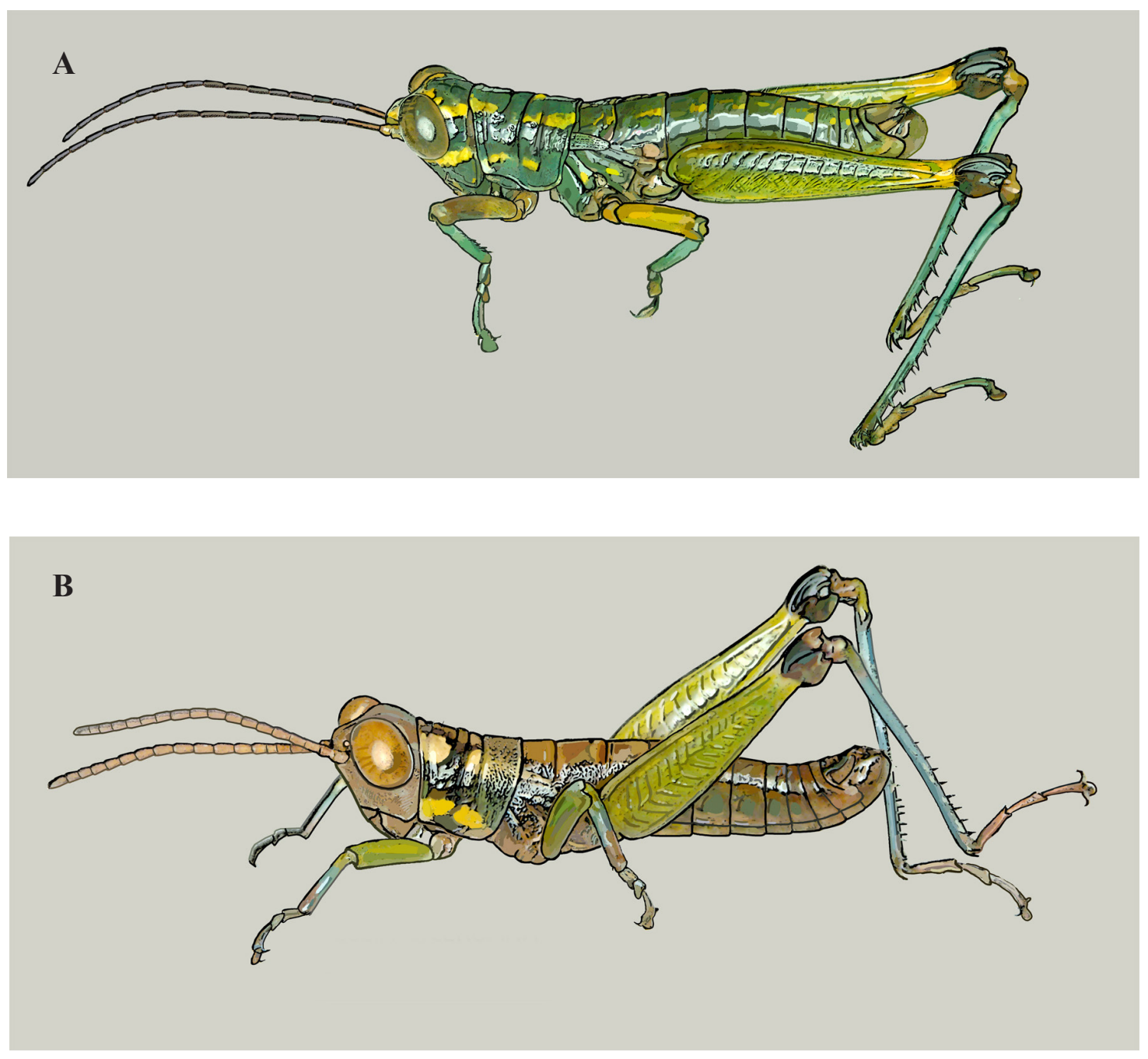

Figure 1. Portraits of males of the two new species. A, Dellia viridissima sp. nov. B, Dellia ciceroana sp. nov.

Description.- Coloration. Predominantly light brown on head and abdominal dorsum, with all legs bright green. Head: face, genae and head vertex light brown, antennomeres reddish, whitetipped. Thorax: pronotum marked by four whitish to yellowish rounded blotches on anterior and posterior margins dorsally, these delimited by black line that surrounds center of pronotal disk which is light brown. This light brown color extends backwards and is continuous with light brown tone of abdominal dorsum. Pronotal sides tinged darker green, delimited below by light brown to yellowish band on lower lateral margin. In preserved specimens darker green has become closer to black. Epimera light brown, epimeron 3 with green tones. Vestigial tegminae: whitish with some green on ventral margin. Abdomen: generally light brown, especially on dorsum. Tympanum lighter brown. Legs: fore and middle legs brighter green than thorax, especially on femora. Lower portion of tibiae reddish, tarsi and claws also reddish. Hind legs bright green, except for small yellow area proximal to black knees. Hind tibiae bluish, while hind tarsi and claws reddish. External genitalia: cerci light brown, furculae and lateral margins of epiproct black. Central area of epiproct light brown. 
Morphology: size of both sexes typical of Dellia species (18-23 mm) and slender. Body integument somewhat shiny, with little pilosity except on legs and abdominal ventral surface. Head: relatively large and globose, with vertex somewhat depressed between eyes. Fastigium only produced slightly beyond eyes, continued by frontal ridge with non-parallel carinae. Antennae filiform, made of $\sim 20$ antennomeres, most over $2 \mathrm{X}$ longer than wide. Thorax: pronotum dorsally slightly longer than head length, saddle shaped, cut near center by three well-marked sulci and lacking medial carinae. Anterior pronotal margin very slightly produced forwards and with small medial concavity. Posterior pronotal margin only barely notched medially, lateral margins straight without lobe. Prosternal spine not exceedingly large, sub-pyramidal. Vestigial tegminae: markedly reduced, narrow and spatulate, barely reaching $2^{\text {nd }}$ visible abdominal tergite. Abdomen: abdominal segments not bearing well-marked dorsal carina. Tympanum present. Legs: not particularly robust in relation to body size, not carinated on dorsal or ventral surface. Hind femora not markedly thickened, with black knees smooth and without genicular spines. Hind tibiae pilose, with 9 external and 8 internal black-tipped spines, the internal ones being slightly longer. Pro and meso tarsi nearly equal in length, metatarsi slightly longer. External genitalia: furculae triangular but not markedly developed. Epiproct sub-quadrangular, typical of Dellia with central area bearing medial broadly flattened ridge with sides depressed (Fig. 3, G-L). Internal genitalia (Fig. 3, A-I): Epiphallus bridge-like with ancorae small, short bridge
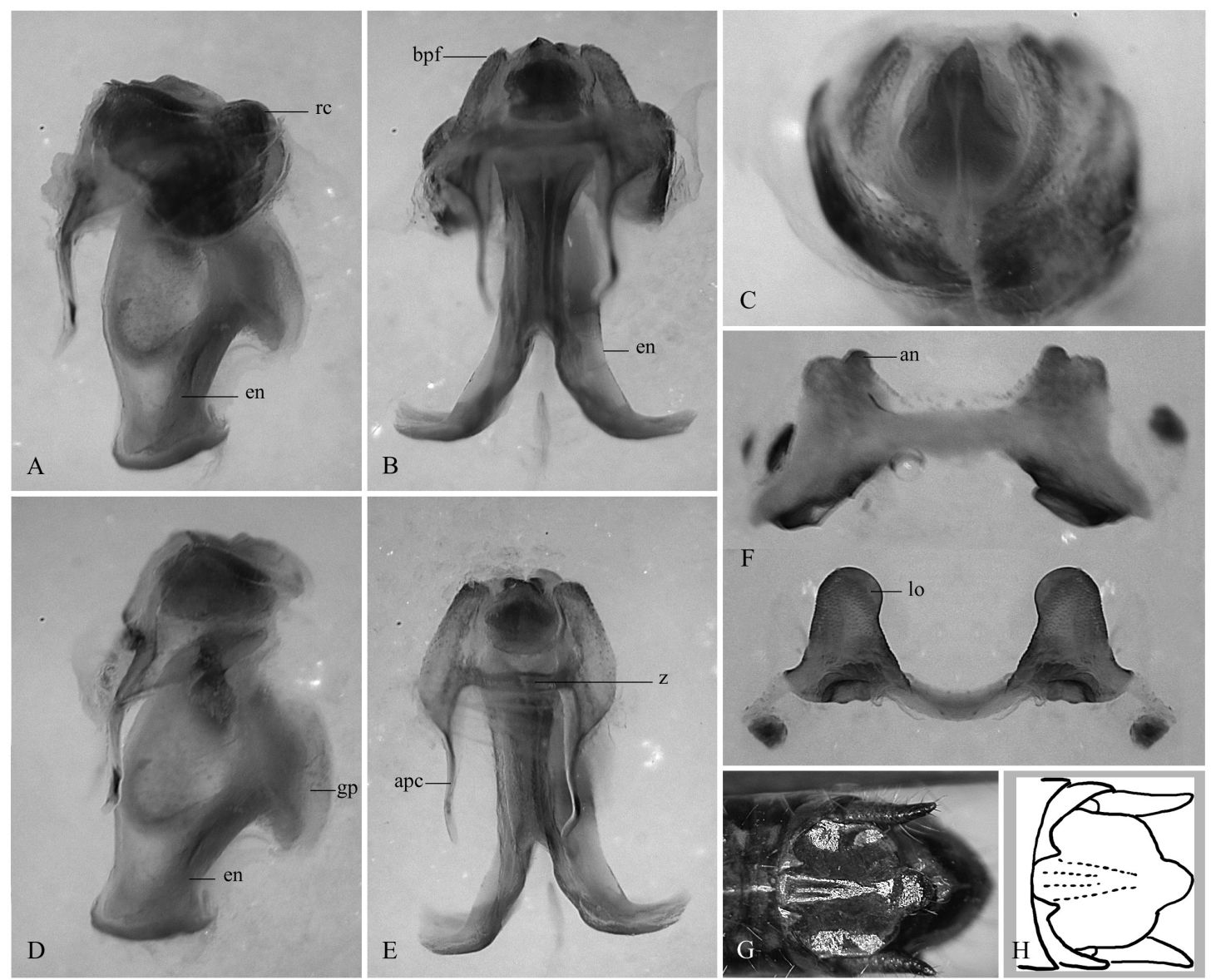

Figure 2. Male genital complex of Dellia viridissima sp.nov. A - B, entire complex showing lateral and dorsal views. C (rear view), D - E, genitalia with basal phallic fold removed (dorsal view). F, epiphallus showing dorsal and posterior views. G, dorsal view of male supragenital plate. $\mathrm{H}$, sketch of male supragenital plate (dorsal) — an, ancorae; apc, apodeme of cingulum; bpf, basal phallic fold; en, endophallic plate; gp, gonopore plate; lo, lophi of epiphallus; rc, ramus of cingulum; z, zygoma. 

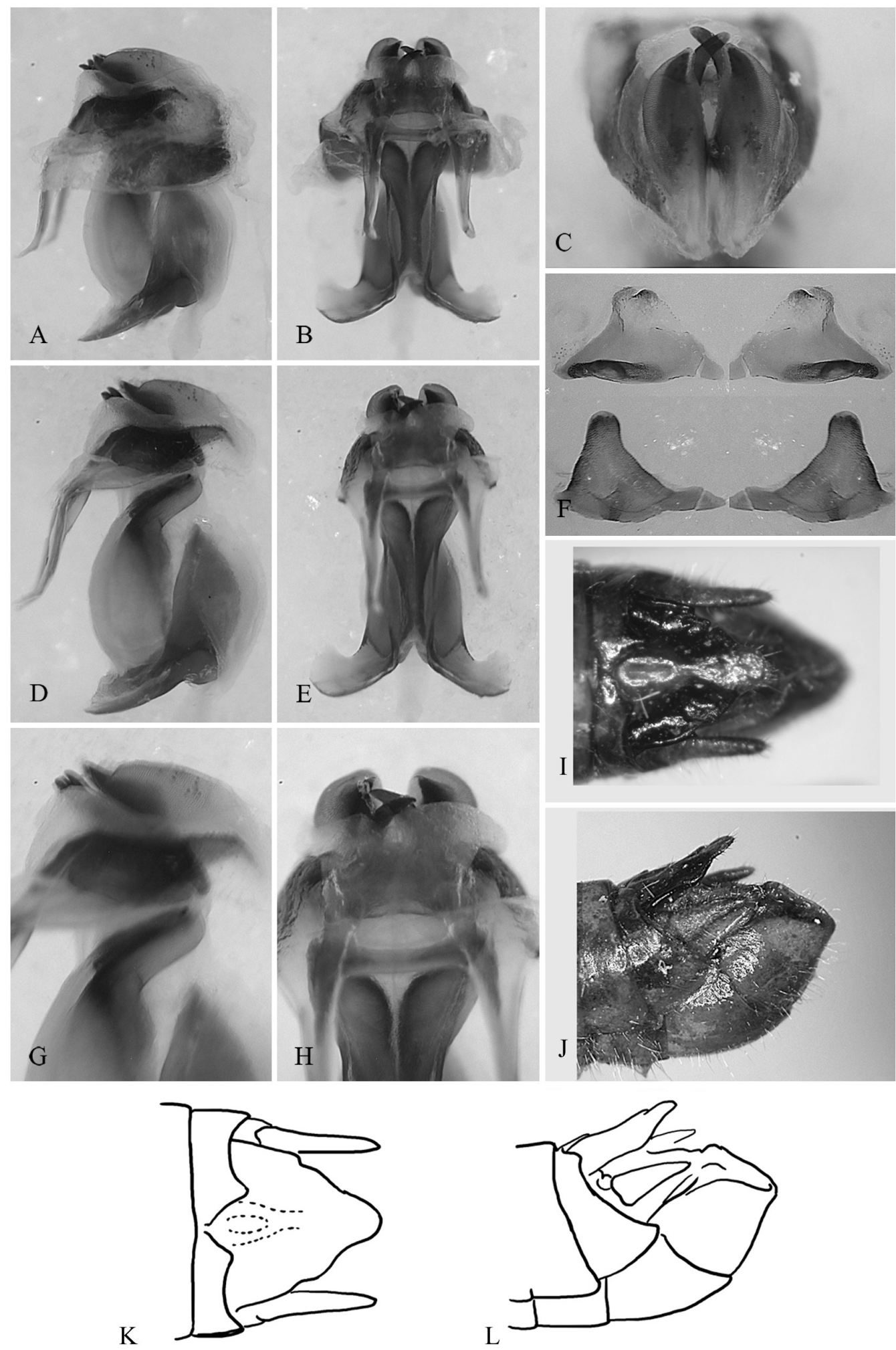

Figure 3. Male genital complex of Dellia ciceroana sp. nov. A-E, genitalia with cingulum removed. F, epiphallus, dorsal and ventral. G, external genitalia, showing epiproct (supragenital plate). J, lateral view of male abdominal end; K-L, sketches of epiproct and abdominal end (dorsal and lateral). 
connecting lateral processes appearing segmented. Lophi rounded but not markedly thickened. Apodemes of cingulum short, only slightly curved upwards. Ramus of cingulum not very wide, with gonopore plate and ejaculatory sack markedly different from that of $D$. viridissima sp. nov.

Female: Colored similarly to males, body larger and more robust. Valves of ovipositor rather short, not particularly robust, bearing no teeth on dorsal surface. Subgenital plate longer than wide, posteriorly terminated in a large pointed medial tip at sides of two large lateral pointed processes.

Etymology. This species is dedicated to the late Professor Julio Cicero Mac-Kinney, SJ., in celebration for his many years as a beloved mentor to several generations of Biology and Agronomy students in the Dominican Republic.

Type material. HOLOTYPE: Male, DOMINICAN REPUBLIC, RD-270 2 km E Puerto Escondido, Independencia Prov., 450 m, $18^{\circ} 19.652^{\prime} \mathrm{N} 71^{\circ} 34.156^{\prime} \mathrm{W}, 14 . v i i .2004$, D. Perez (d) [diurnal] (ANSP). Allotype: Female, same data as holotype (both specimens were collected while together tough not in copula) (NMNH). Paratype: Male, DOMINICAN REPUBLIC, RD-135 $\sim 7 \mathrm{~km}$ Rd. to Caseta 1, Parque Nacional Sierra de Bahoruco, Independencia Prov., $18^{\circ} 17.711^{\prime} \mathrm{N} 71^{\circ} 34.335^{\prime} \mathrm{W}, 777$ m, 3.vii.2003, D. Perez, R. Bastardo, B. Hierro. (day) (NMNH).

Measurements (mm).-Male 1(Holotype): body length: 18.13; head length: 2.75; pronotum length: 3.13 ; interocular distance: 0.50 ; length of hind femur: 10.63 . Male 2: body length: 17.00 ; head length: 2.50; pronotum length: 3.00; interocular distance: 0.50 ; length of hind femur: 9.75 . Female: body length: 22.50; head length: 3.13 ; pronotum length: 3.88 ; interocular distance: 0.88 ; length of hind femur: 12.13 .

\section{DISCUSSION}

Dellia is a West Indian endemic genus of colorful semi-arboreal grasshoppers that inhabit dry to wet forests from coastal to montane habitats, often with seemingly sparse populations. The genus is known from Cuba, Jamaica, Hispaniola and the Bahamas, now with a total of 10 described species. So far it has not been found in Puerto Rico. All known species are single island endemics.

The two species described here are not closely related, besides their external differences, their genitalia are also markedly different. Actually $D$. viridissima sp. nov. could be thought as an outlier among Hispaniolan Dellia (initially we thought it could be classified as a different genus). Among the most notable particularities of $D$. viridissima sp. nov. are the nearly all green coloration, a more produced fastigium of vertex, eyes less rounded, and a thicker genital complex.

The mountains of Sierra de Bahoruco have been identified as one of the main centers of plant endemism in Hispaniola, harboring a disproportionately large fraction of the endemic plant genera (12 out of 33,36.4\%) found on the island (García et al., 2001). Correspondingly, many species of invertebrates are exclusively found in the various types of forests occurring in these mountains. Figure 4 shows some of the oppulent wet vegetation found at Cortico, Monteada Nueva. The nine grasshopper specimens of D. viridissima sp. nov. collected in January 2002 were all found in close association with the plant Solandra longiflora Tuss. (Solanaceae), although none were observed feeding on it. This is a climbing vine with large broad leaves found scattered in this wet forest. The individuals of D. viridissima sp. nov. were collected on three aggregations of this plant after persistent search for about two hours. One pair was found in copula. 


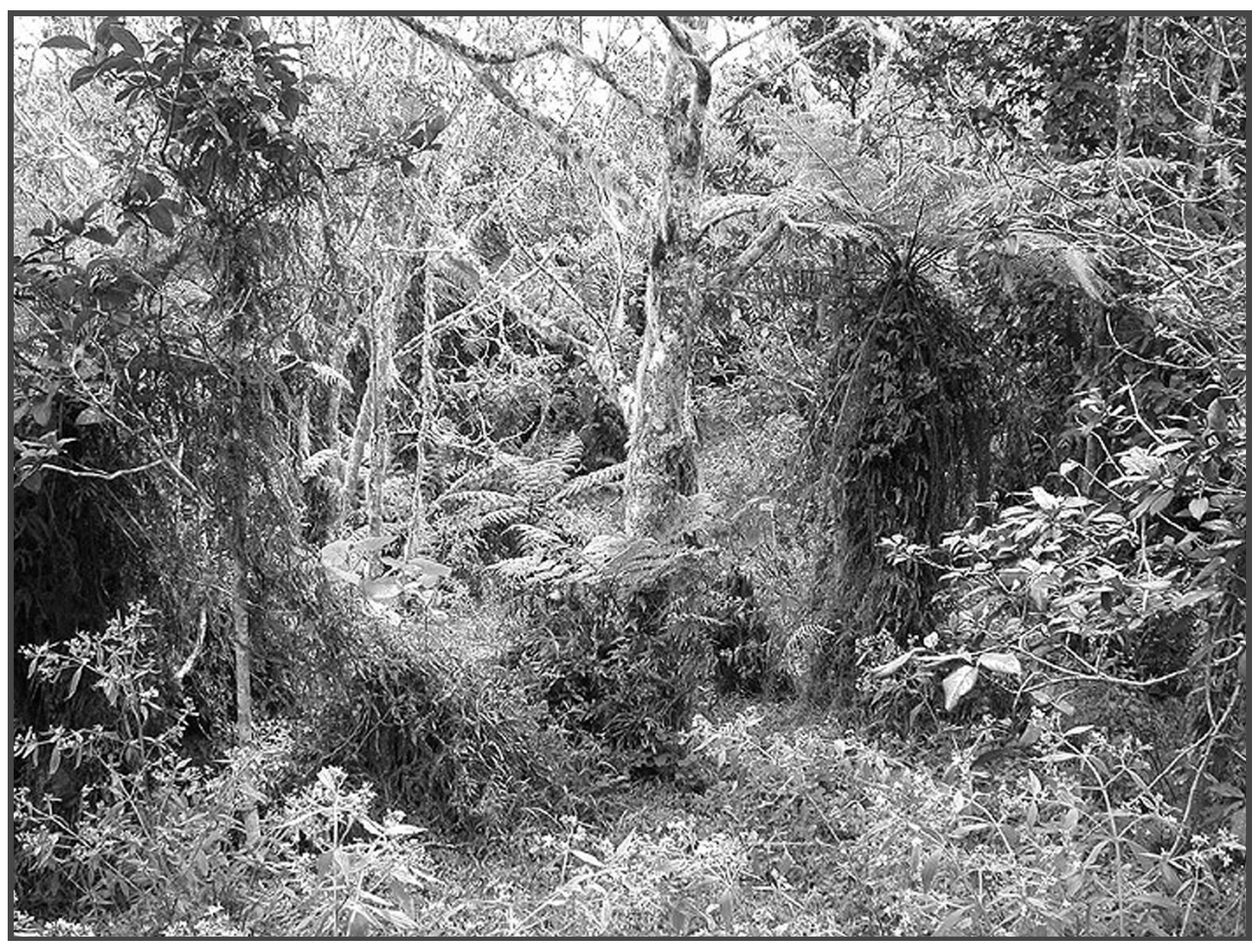

Figure 4. A view of the habitat of Dellia viridissima sp. nov. in Cortico, Monteada Nueva, eastern Sierra de Bahoruco.

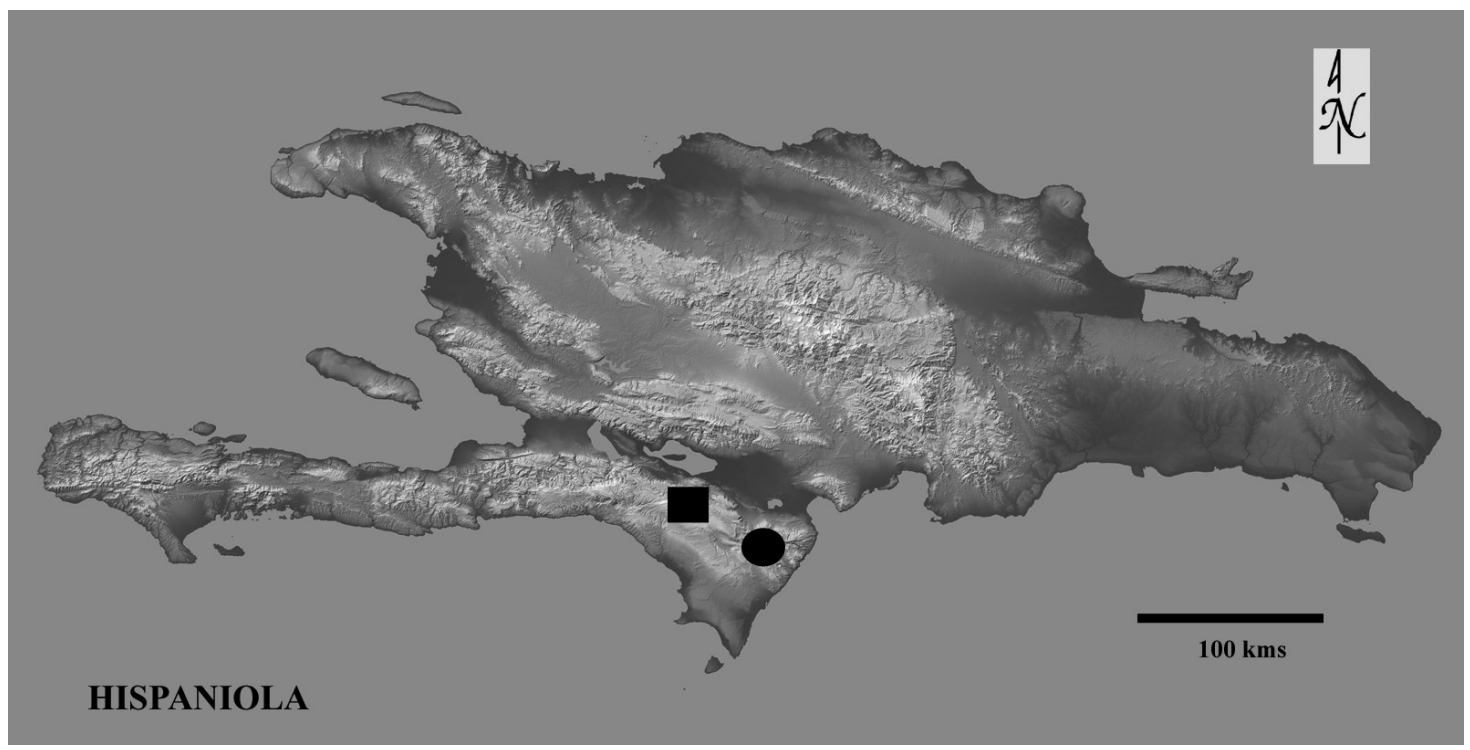

Figure 5. Known distribution of Dellia viridissima sp. nov. (circle) and Dellia ciceroana sp. nov. (square) in Sierra de Bahoruco, southwestern Dominican Republic, Hispaniola. 
The first individual of this species was collected by the senior author in a serendipitous manner fifteen years earlier (1987), finding it within his collecting net which had been left overnight outside the camping tent. The speculation was that the individual was probably attracted to the grasshopper smells imbibing the net. No other specimens were found during three subsequent but short visits to the area. The cloud forest at Cortico, Monteada Nueva has been seriously impacted by deforestation, mainly in relation to agriculture and cattle ranching.

The forest near Puerto Escondido is drier and seems to be a transition zone to the higher areas of the southern slopes of Sierra de Bahoruco. The vegetation there is varied containing many species typical of the dry forest at higher altitudes, then at higher elevations becoming a pine forest with a lower stratus of diverse shrubs. D. ciceroana sp. nov. was found at two sites suggesting that the species inhabits the altitudinal band between $450-800$ meters.

The genus Dellia is now known to include at least six species in Hispaniola, distributed from the coast to montane habitats at elevations up to 1,300 meters. $D$. dominicensis seems to have a rather wide distribution, mostly across the southern part of the Dominican Republic, having been collected from the coast to mountains in San Pedro de Macorís to Azua provinces. D. roseomaculata is associated with the mountains of the Cordillera Central and is known from Elias Piña, Santiago and La Vega provinces. D. bayahibe is known from the forests in and around Parque del Este. D. monticola is another species from Sierra de Bahoruco, being known only from around $600 \mathrm{~m}$ elevation at El Aceitillar, Pedernales province. No specimens of Dellia have so far been collected in Haiti.

\section{KEY TO THE KNOWN SPECIES OF DELLIA IN HISPANIOLA (MALES).}

1. Body color mainly dark green with bright yellow spots and bands .....D. viridissima sp. nov.

--- Body color a combination of green, red, yellow and other colors .................. 2

2. Epimera marked by a reddish spot. Distributed in central and northern of Cordillera Central D. roseomaculata

--- Epimera marked by a yellowish spot or by no spot. Distributed across the southern portion of

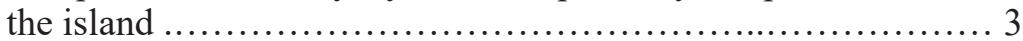

3. Cerci relatively thick and slightly curved. 10th abdominal tergum with furculae small and rounded D. monticola

--- Cerci relatively slender and straight. 10th abdominal tergum with furculae triangular ..... 4

4. Pronotum with large dorsal yellowish spots ...................... D. ciceroana sp. nov.

--- Pronotum without dorsal spots ....................................... 5

5. Dorsal abdominal area mainly whitish in coloration ..................... D. bayahibe

--- Dorsal abdominal area mainly brown in coloration ................. D. dominicensis

\section{ACKNOWLEDGMENTS}

We thank Ruth Bastardo (Instituto de Investigaciones Botánicas y Zoológicas, Universidad Autónoma de Santo Domingo), Brígido Hierro (Dirección de Biodiversidad, Ministerio de Medio Ambiente, Santo Domingo) and Sardis Medrano (Instituto Dominicano de Investigaciones Agropecuarias y Forestales, Santo Domingo) for their valuable assistance and enthusiasm with fieldwork during the Hispaniolan Orthopteroids Project. Francisco Jiménez (Jardín Botánico Nacional, Santo Domingo) graciously provided the identification of Solandra longiflora. 
Lucrecia H. Rodríguez (Systematic Entomology Lab, United States Department of Agriculture) helped to complete and improve the figures and plates. Jens Prena (Systematic Entomology Lab, United States Department of Agriculture) made important improvements to the language of the manuscript. The Departamento de Vida Silvestre (Secretaría de Medio Ambiente, Santo Domingo) issued our collecting and export permits. Our field work in the Dominican Republic was made possible by funds of the National Science Foundation project DEB-0103042.

\section{LITERATURE CITED}

Amédégnato, C., A. Ruíz-Baliú and C. S. Carbonell. 1995. Acridiofauna cubana (Orthoptera): Sinópsis de su taxonomía y origen. Revista Brasileira de Entomologia, 39: 683-708.

Carl, J. 1916. Acridoides nouveaux ou peu connus du Museum de Genève. Revue Suisse de Zoologie, 24: 461-518.

García, R., M. Mejía, B. Peguero and F. Jiménez. 2001. Flora endémica de la Sierra de Bahoruco, República Dominicana. Moscosoa, 12: 9-44.

Perez-Gelabert, D. E. 2000. New locality and island records for seventeen species of West Indian grasshoppers (Orthoptera: Caelifera). Caribbean Journal of Science, 36: 335-340.

Perez-Gelabert, D. E. 2001. Two new species of grasshoppers, Dellia karstica spec. nov. and Dellia maroona spec. nov. (Orthoptera: Acrididae) from the Cockpit Country, Jamaica. Journal of Orthoptera Research, 10: 75-80.

Perez-Gelabert, D. E. 2002. A new species of Dellia Stål (Orthoptera: Acrididae) from Eastern Dominican Republic. Solenodon, 2: 31-37.

Perez-Gelabert, D. E., G. O. Dominici, B. Hierro and D. Otte. 1995. New grasshopper genera and species from the Dominican Republic (Hispaniola) (Acridoidea: Acrididae). Transactions of the American Entomological Society, 121: 153-171.

Perez-Gelabert, D. E. and D. Otte. 1999. Dos nuevas especies de saltamontes del género Dellia (Orthoptera: Acrididae) de la República Dominicana. Novitates Caribaea, 1: 1-13.

Rehn, J. A. G. and M. Hebard. 1938. New genera and species of West Indian Acrididae, with notes on previously known species. Transactions of the American Entomological Society, 64: 201-226.

[Recibido: 16 de febrero, 2012. Aceptado para publicación: 10 de abril, 2012] 